\title{
Prognostic and predictive markers for perineural and bone invasion of oral squamous cell carcinoma
}

\author{
Jaroslav Michalek ${ }^{\mathrm{a}}$, Svetlana Brychtovaa ${ }^{\mathrm{a}}$, Richard Pink ${ }^{\mathrm{b}}$, Zdenek Dvorak $^{\mathrm{c}}$
}

\begin{abstract}
Oral squamous cell carcinoma (OSCC) is a growing problem worldwide. Several biological and molecular criteria have been established for making a prognosis of OSCC. One of the most important factors affecting the risk of tumor recurrence and overall prognosis is perineural invasion and bone invasion. Perineural invasion is defined as a tumor spreading and the ability of tumor cells to penetrate around or through the nerve tissue. Perineural invasion can cause the tumor to spread to distant areas from the primary tumor location. One possible explanation for this is the formation of microenvironment in the perineural space which may contain cellular factors that act on both nerve tissue and some types of tumor tissues. Bone invasion by OSCC has major implications for tumor staging, choice of treatment, outcome and quality of life. Oral SCCs invade the mandibular or maxillary bone through an erosive, infiltrative or mixed pattern that correlates with clinical behavior. Bone resorption by osteoclasts is an important step in the process of bone invasion by oral SCCs. Some cytokines (e.g. TNFa and PTHrP) lead to receptor activator of NF-KB ligand (RANKL) expression or osteoprotegerin (OPG) suppression in oral SCC cells and in cancer stromal cells to induce osteoclastogenesis. Oral SCCs provide a suitable microenvironment for osteoclastogenesis to regulate the balance of RANKL and OPG. A more molecular-based clinical staging and tailor-made therapy would benefit patients with bone invasion by OSCC.
\end{abstract}

Key words: squamous cell carcinoma, oral cavity and oropharynx, bone invasion, perineural invasion

Received: April 16, 2019; Accepted: June 26, 2019; Available online: August 21, 2019

https://doi.org/10.5507/bp.2019.032

(c) 2019 The Authors. This is an open access article licensed under the Creative Commons Attribution License

(https://creativecommons.org/licenses/by/4.0/).

aDepartment of Clinical and Molecular Pathology, Faculty of Medicine and Dentistry, Palacky University Olomouc and University Hospital Olomouc, Czech Republic

${ }^{b}$ Department of Oral and Maxillofacial Surgery, University Hospital Olomouc, Czech Republic

'Department of Plastic and Aesthetic Surgery of St. Anne's University Hospital and Faculty of Medicine, Masaryk University Brno, Czech Republic

Corresponding author:Zdenek Dvorak, e-mail:zdenek.dvorak@fnusa.cz

\section{INTRODUCTION}

Squamous cell carcinoma of the head and neck (SCC) originates from the mucosal lining of the upper aerodigestive tract, thus including cancers of the oral cavity, pharynx, and larynx. According to recent estimates, more than 650,000 new cases are diagnosed and over 350,000 cancer deaths reported every year worldwide ${ }^{1}$. Despite supporting health education and improving awareness among the general public and primary care practitioners, the majority of patients are still diagnosed in advanced stages of disease (stages III and IV). Such cases usually require a multimodality approach, albeit most of them, unfortunately, develop recurrences or distant metastases, eventually succumbing to their disease ${ }^{2}$. The etiology of SCC is typically linked to tobacco and alcohol abuse. However, emerging evidence has revealed an increasing proportion of oropharyngeal carcinomas caused by human-papillomavirus (HPV) infection. As a result, two biologically distinct types of SCC (HPV-positive and HPV-negative) can be distinguished. In the United States, HPV-positive oropharyngeal cancer is the fastest rising malignant disease in young white $\mathrm{men}^{3}$. This alarming trend is expected to be evident in other economically developed countries.
In the Czech Republic, the incidence and mortality for oral cavity and pharynx cancers in 2016 was 1654 and 756, respectively. Almost half of the newly diagnosed cases were classified as stage IV disease. In men, excluding non-melanoma skin cancers, SCC of the oral cavity, pharynx, and larynx was the sixth most frequent neoplasm in terms of incidence and the fifth leading cause of cancer deaths. Interestingly, these tumors are far less common in women and the gender-specific differences have not been successfully explained yet ${ }^{4}$.

\section{PROGNOSTIC FACTORS OF ORAL SQUAMOUS CELL CARCINOMA (OSCC)}

Several biological and molecular criteria have been established for the determination of histopathological staging of SCC, which play a key role in the post-surgery treatment and estimation of prognosis of carcinoma of oral cavity and oropharynx $x^{5}$. Prognosis in oral SCC depends on the localization and volume of tumor, histopathological grading, histological type of squamous cell carcinoma, positivity of surgical edges, occurrence of regional and distant metastasis and the other signs of 
aggressive and malignant behavior (perineural invasion, endovascular invasion, bone invasion).

\section{PERINEURAL INVASION}

Perineural invasion (PNI) is defined as tumor spreading and the ability of tumor cells to penetrate into, around or through the nerve tissue (Fig. 1) (ref. ${ }^{6}$ ). This process has been well described in colorectal carcinoma and salivary gland malignancies but not studied in detail in squamous cell carcinoma ${ }^{7,8}$. A possible cause of the perineural proliferation is based on the chemotropism of tumor cells that can be stimulated by nerve tissue to undergo further growth. However, this process can function the other way around, with the tumor inducing the growth of the nerve tissue. The increase of tumorous invasion into the tissue causes the tumor spreading into distant areas from the primary tumor location. In the past, it was proposed that the mechanical invasion of tumorous tissue occurs due to the relatively thin epineurium tissue ${ }^{9}$. This theory was however rejected after the improvement of microscopic techniques, which revealed that the tumorous cells did not grow passively around the nerves, but penetrated through the perineurium up to a close proximity of Schwann cells and axons in the endoneurium ${ }^{10}$. Interestingly, some less aggressive tumors develop this nerve-tumor complex at relatively early stages while other, more aggressive tumors cause perineural invasion only at an advanced stage ${ }^{11}$. One possible explanation is the formation of microenvironment in the perineural space, which may contain certain cellular factors that act not only on nerve tissue but also on some types of tumorous tissues. Using cDNA microarray on adenoid cystic carcinoma samples with and without perineural invasion, a deregulation of genes controlling cell cycle, cytoskeleton and extracellular matrix has been described. The extracellular matrix contained increased amounts of neurotrophic factors and adhesive molecules, which promoted tumor spreading on the basis of chemotaxis. Liebig proposed to define the perineural invasion as a tumor invasion in the proximity of a nerve comprising $1 / 3$ of the nerve circuit and/or showing the presence of tumorous cells in any of the three nerve layers $^{12}$. Unfortunately, this classification cannot distinguish between perineural proliferation without infiltration of the nerve fascicle and intraneural propagation or penetration of the cells directly into the nerve, which may have a direct clinical impact and affect the patient's prognosis. This fact also illustrates the importance of a detailed research of this process for patient therapy as distinguishing between these two processes can serve as an important indicator of the tumor aggressiveness, thus giving an information affecting survival and/or likelihood of the local recurrence of the tumor. In clinical studies, the presence of perineural invasion normally ranges from 2 to $30 \%$ but a rate as high as $82 \%$ was also reported, depending on the type of tumor and used detection methods ${ }^{13-16}$. A perineural invasion of the squamous cell carcinoma has been demonstrated but not explored in detail. In clinical trials investigating squamous cell carcinoma in the orofacial

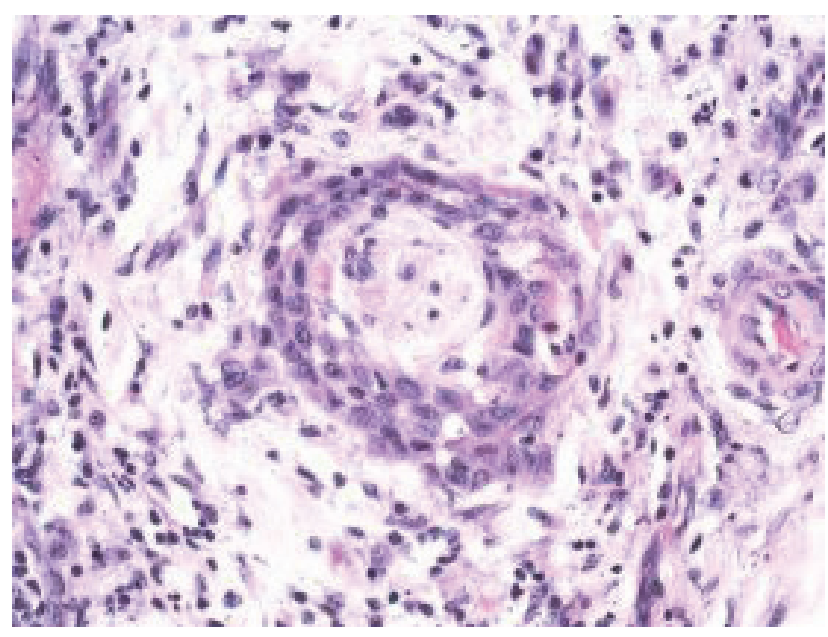

Fig. 1. Perineural spreading of oral squamous cell carcinoma (Hematoxylin and Eosin staining, 100x).

area, this invasion can be a significant independent factor that increases local recurrence of the tumor, metastases and median patient survival ${ }^{17-19}$. In the orofacial area, it has been shown that the presence of perineural invasion can, for example, cause intracranial spreading of lip carcinoma along the facial or trigeminal nerve branch, thereby negatively affecting the patient prognosis ${ }^{20,21}$. However, the results of previous studies are not consistent; for example, Wallwork did not find a statistically significant correlation between perineural invasion and lymphogenic metastases of carcinomas in the oral cavity ${ }^{22}$, while other sources confirm this correlation statistically significant ${ }^{5,23,24}$. Another study revealed association between lymphonodal and perineural invasion of T1-T2 carcinomas of the anterior part of the tongue ${ }^{25}$. And another study stated that the tumor thickness, "noncohesive invasion front", neural and bone invasion are powerful factors affecting the lymphonodal spreading of the tumor ${ }^{26}$. Theoretically, therefore, perineural proliferation may be another important factor for clinical practice, particularly in younger patients, whose tumors are generally described as being more aggressive, although this is not fully confirmed in the literature. The interactions between tumor and neural cells is not only limited to cell migration and tumor growth from the primary location but such interaction can also stimulate axonogenesis or extend the nerves themselves together with increasing number of axons. This increase of neurons can lead to an increase of tissue density surrounding the neural tissue. The process is important in embryonic development or in wound healing where it is physiologi$\mathrm{cal}^{27}$. In oncology, unfortunately, this process facilitates tumor progression, as demonstrated in adenoid cystic carcinoma, which was proved to release neural growth factors into surrounding tissues. This stimulated nervous tissue causes nerve elongation, which allows the tumor to spread further into the tissue ${ }^{28}$. A similar phenomenon has been demonstrated in the prostate tumor, where the nerve - tumor complex formed a microenvironment stimulating both the nerve and the tumor to grow with each other ${ }^{29}$. Whether squamous cell carcinoma also affects neurogenesis in a similar way remains unclear ${ }^{18}$. 


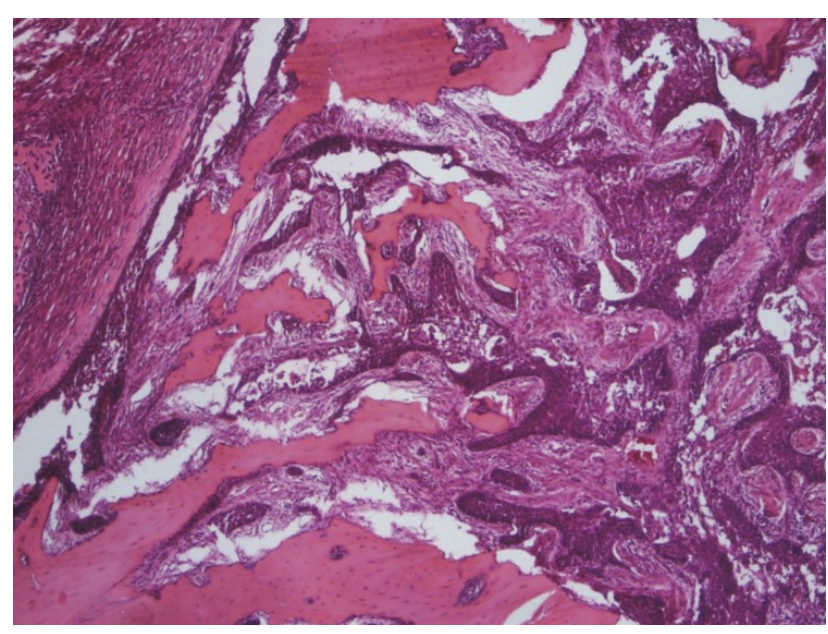

Fig. 2. Infiltrative form of bone invasion by oral squamous cell carcinoma (Hematoxylin and Eosin staining, 40x).

\section{BONE INVASION}

Due to the intimate relationship of oral SCC to the jawbone and the relatively rapid growth, this tumor, especially gingival carcinoma, often invades bone tissue ${ }^{30}$. Carcinomas that grow through the cortical bone are classified by TNM as the pT4a pathological stage. Surface erosion of the bone itself is however not sufficient to classify the tumor as pT4 (ref. ${ }^{31}$ ). Recently, the maxillary/ mandibular invasion can be diagnosed by radiological methods without the need to perform a surgical intervention. However, radiology can not reliably distinguish whether the tumor is causing invasive bone resorption or whether is only in contact with the bone without invasive bone progression. The radiological diagnosis by itself is therefore inadequate, especially in upper gingival cancer, and development of new diagnostic techniques is needed to allow an accurate assessment of the bone invasion extent $^{32}$. Histologically, we recognize three types of bone invasion: erosive, infiltrative and mixed. The infiltrative form (Fig. 2) is characterized by a formation of irregular nests and projections of tumorous cells into the bone, their penetration into the Haversian system and the presence of residual bone islets inside the tumor. The erosive form of bone invasion (Fig. 3) is, on the contrary, characterized by a sharp transition between the tumor and the bone, osteoclastic bone resorption, fibrosis along the tumor and absence of bone islets within the tumor. The mixed form combines both types of invasion in one tumor $^{33,34}$. The histological character of bone invasion correlates with the clinical behavior of the tumor - infiltrative lesions are more likely to show primary, regional or distant recurrence of the tumor. The invasion of squamous cell carcinoma into the bone is a histological parameter that determines the type and extent of oncology treatment (resection of the lower jaw) - the erosive form of bone invasion can be treated with marginal mandibulectomy rather than segmental resection ${ }^{35}$.

Activation of bone-resorbing osteoclasts seems to be the most important in bone invasion by OSCC, also referred to as osteoclastogenesis ${ }^{36-40}$. In a physiological

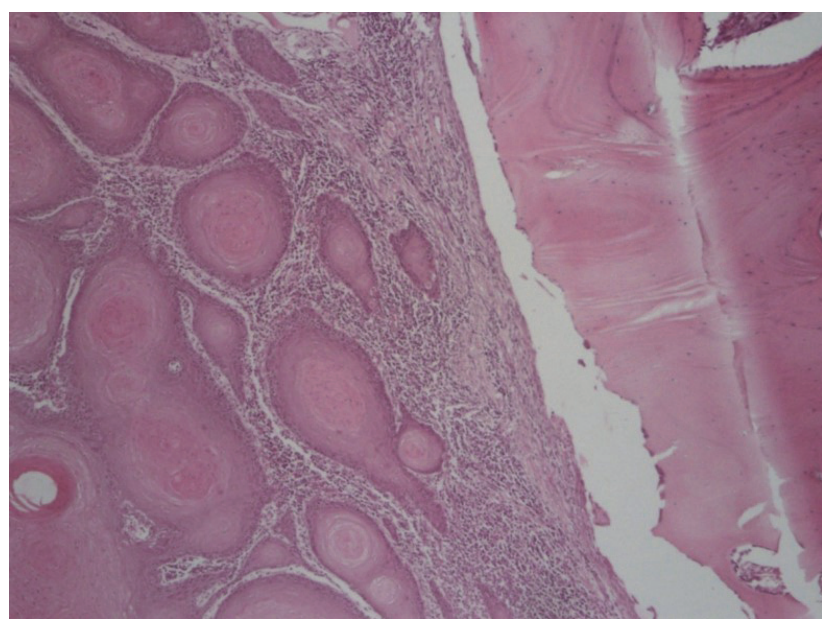

Fig. 3. Erosive form of bone invasion by oral squamous cell carcinoma (Hematoxylin and Eosin staining, 40x).

situation bone-resorbing osteoclasts and bone-forming osteoblasts are balanced. Osteoclastogenesis can be activated in several ways, for example: the osteoclast activation controlled by RANK-RANKL-OPG pathway, VEGF or copper ${ }^{41-44}$.

\section{Molecular mechanisms of bone invasion by OSCC}

\section{RANK-RANKL-OPG pathway}

Malignant cells produce a lot of enzymes (e.g. matrix metalloproteinases, cathepsins) that can destroy bone tissue directly and enhance the migration of cancer cells into adjacent tissues. Moreover, these proteolytic enzymes act especially on osteoclast precursors to promote their differentiation and maturation ${ }^{45,46}$. Three proteins crucial for osteoclast development and activation are the tumor necrosis factor (TNF)-related proteins RANKL (receptor activator for nuclear factor $\mathrm{\kappa B}$ ligand; expressed in osteoblasts and bone marrow stromal cells), its receptor RANK (receptor activator of nuclear factor $\kappa \mathrm{B}$; expressed in osteoclast progenitors and mature osteoclasts), and its soluble decoy receptor OPG (osteoprotegerin; synthesized by osteoblasts and bone marrow stromal cells) ( ref. $^{37}$ ). Tada et al. showed that suppression of OPG induced by tumor may be critical in OSCC bone invasion. A low expression of OPG in osteoblasts and stromal cells in the lesion was seen in patients with OSCC with bone invasion. In non-affected bone of the same individuals the OPG expression was normal ${ }^{47}$. Cui et al. showed that carcinomas with the potential for bone invasion express factors that allow further maturation of osteoclast progenitors, e.g. IL-1 $\alpha$, IL-6, TNF- $\alpha$ and parathyroid hormone-related protein (PTHrP). They concluded that only tumor tissues with the ability to express sufficient osteoclast-related cytokines promote the differentiation of pre-osteoclasts and osteoclasts to induce bone invasion ${ }^{48}$. Fibrous stroma is intervened between tumor and bone in the majority of cases of OSCC, with no direct contact between cancer cells and bone. IL- 6 and PTHrP produced by OSCC cells and IL- 6 produced by stromal cells induce fibroblasts/ 
osteoblasts to synthesize RANKL and they subsequently induce osteoclast formation and thus bone invasion ${ }^{49,50}$. The resorption of bone releases growth factors, e.g. fibroblast growth factor (FGF) and transforming growth factor- $\beta$ (TGF- $\beta$ ). Release of those osteoclast-related cytokines stimulates tumor proliferation and leads to an upregulation of PTHrP, which results in a vicious circle of osteoclastogenesis and tumor progression ${ }^{40,47,48,51}$. TGF- $\beta$ and epidermal growth factor (EGF) are potent effectors of epithelial-mesenchymal transition (EMT) - a crucial step in bone invasion by malignant epithelial cells. EMT causes cancer cells to become more migratory, leading to invasion into stroma, intravasation and dissemination ${ }^{52,53}$. In EMT, the expression of the major adhesion molecule of epithelial cells, E-cadherin, is suppressed by the expression of Snail, the transcriptional repressor of E-cadherin, and carcinoma cells comprising tumor nests lose contact and are cellularized. TGF- $\beta$ induces EMT and treatments with TGF- $\beta$ not only suppress the expression of E-cadherin, but also induce that of mesenchymal markers. Furthermore, recent studies confirmed that cancer cells with the TGF- $\beta$ signal induce matrix metalloproteinases and generate cancer stem cells and cancer-associated fibroblasts. Therefore, the detection of EMT or EMT markers, including a decrease in or the loss of E-cadherin expression or the induction of N-cadherin, Snail, and vimentin expression in carcinoma cells, is expected to play a valuable role in prognostic predictions for patients with carcinomas $^{54}$. EMT is also important in the progression of bone invasion by OSCC ( ref. $^{55}$ ). The loss of E-cadherin in tumour cells may be utilized by monocytes to differentiate into osteoclasts, thus further explaining the underlying mechanisms of bone invasion by OSCC, which may supply clues for future molecular biotherapies ${ }^{56}$.

\section{VEGF}

Vascular endothelial growth factor (VEGF) is a highly specific signaling protein for vascular endothelial cells that plays a critical role in tumor growth and invasion through angiogenesis, and may contribute to cell migration and activation of pre-osteoclasts, osteoclasts and some tumor cells. VEGF-Flt-1 signaling induces osteoclastogenesis in OSCC through two possible ways:

1) VEGF produced from OSCC cells can directly stimulate the Flt-1 pathway in pre-osteoclasts to induce migration to future bone resorbing area and differentiation into osteoclasts.

2) VEGF-Flt-1 signaling upregulates RANKL expression in OSCC cells, which indirectly leads to osteoclast differentiation ${ }^{43}$.

\section{COPPER and LYSYL OXIDASE}

Copper has been demonstrated to play a key role in skeletal remodeling. However, the role of copper in cancer-associated bone destruction is unknown. Lysyl oxidase (LOX) is a copper-dependent enzyme that promotes osteoclastogenesis. Morisawa et al. investigated the effects of copper on OSCC with bone invasion by the copper chelator, ammonium tetrathiomolybdate (TM). It was demonstrated that TM blocks the proliferation of OSCC cells, inhibits LOX activation and decreases the expression of the receptor activator of nuclear factor- $\mathrm{\kappa} B$ ligand (RANKL) in osteoblasts and osteocytes, subsequently suppressing bone destruction ${ }^{44}$.

\section{DISCUSSION}

Mortality rates and treatment -related morbidity of patients with OSCC are still exceedingly high, challenging the available methods of diagnostic and prognostic assessment, and encouraging the search for new and better tools, namely molecular markers that relate comprehensively to known characteristics of tumor progression and invasiveness ${ }^{57-59}$. The standard approach to the prognosis still relies on classical TNM staging, with metric factors such as tumor size and thickness, and number and size of possible lymphnode or distant metastases ${ }^{31,60}$. Bobdey et al. developed accurate and efficient nomogram to predict the probability of 3-year survival in T4 buccal mucosa cancer patients. The nomogram was built using tumor differentiation, pathological lymph node involvement, bone and perineural invasion. Intensification of adjuvant treatment in advanced cancer patients with poorer score might improve their survival ${ }^{61}$. Multiple factors are possibly involved in growth pattern, and probably no single marker can accurately predict tumor progression. Tumor progression is a multifactorial and multistep process, so multiple marker evaluation may logically be required to estimate bone invasiveness and perineural spreading. Another complexity is the possible intratumoral heterogeneity of the marker, for which multiple tumor sampling may be the key. Analysis of the tumor invasion front is gaining relevance because it might better reflect tumorhost interactions, and consequently the aggressiveness and prognosis ${ }^{52,62,63}$. Perineural invasion is one of the significant risk factors of regional relapse of OSCC, which is connected with low survival of patients. Intensity of perineural invasion correlates with tumor localization, its volume and presence of metastatic lymph nodes. However, up to now little attention was paid to perineural invasion markers in oral squamous cell carcinoma. Possible candidate markers include chemoatractans of primary neural origin such as nerve growth factor (NGF), brain-derived nerve growth factor (BDNF), neurotrophin 3 (NT-3), neurotrophin 4/5 (NT4/5) or chemokines such as semaphorins or ephrins ${ }^{64-70}$.

Bone invasion is another important risk factor for tumor recurrence and worse prognosis and therefore it is necessary to consider adjuvant therapy in patients with medullary bone invasion ${ }^{71}$. Type of bone invasion may be an independent prognostic parameter of the disease and can help to decide how radical the surgical and oncological treatment should be. However, no single marker can precisely predict bone invasion in routine practice. Possible candidate markers for preoperative bone invasion assessment might include markers that are related to the relationship of tumor epithelial cells to tumorous and 
nontumorous mesenchyme (e.g. OPG, RANKL, PTHrP, TNF- $\alpha$, IL-6, IL-11, TGF-beta, relaxin-2).

The aim of future research is to improve diagnosis, which is nowadays based on clinical assessment and radiological imaging. Through molecular-based clinical staging a patient-specific risk assessment for bone invasiveness by OSCC could be defined. Unfortunately, the widespread introduction of biological markers into daily clinical practice has been confusing and rather ineffective, hampering the completion of clinical studies to assess their real usefulness and thus facilitate their definitive implementation. In addition, the scattering of published data complicates translation into the clinical setting. Potential future research can be realized by novel modern possibilities, for example by 3D printed tissue. Recent advances in threedimensional printing technology have led to a rapid expansion of its applications in tissue engineering. The $3 \mathrm{D}$ tissue engineered composite model closely simulates the native oral hard and soft tissues and has the potential to be used as a valuable in vitro model for the investigation of bone invasion of oral cancer and for the evaluation of novel diagnostic or therapeutic approaches to manage OSCC in the future ${ }^{72}$.

The development of targeted approaches to OSCC analysis can contribute to the development of target therapy. The inhibition of osteoclast differentiation and function by blocking RANKL/RANK constitutes a potentially approach to maintaining skeletal integrity and can prevent the development of bone invasion induced by oral SCC ( ref. $^{73}$ ). Blocking of the VEGF-Flt-1 signaling may help inhibit bone invasion of OSCC because VEGF produced from OSCC cells can directly stimulate the Flt-1 pathway in pre-osteoclasts to induce migration to future bone resorbing area and differentiation into osteoclasts, and VEGF-Flt-1 signaling upregulates RANKL expression in OSCC cells, which indirectly leads to osteoclast differentiation ${ }^{43}$. Copper is another potential target for the treatment of OSCC associated with bone destruction because copper can play a key role in skeletal remodeling. Ammonium tetrathiomolybdate, copper chelator, blocks the proliferation of OSCC cells, inhibits lysyl oxidase activation and decreases the expression of RANKL in osteoblasts and osteocytes, subsequently suppressing bone destruction $^{44}$.

\section{Search strategy and selection criteria}

Articles and studies were searched using the PubMed and Web of Science databases. Only English papers were reviewed. The search terms used included "oral squamous cell carcinoma”, "perineural invasion”, "bone invasion” and "oral squamous cell carcinoma prognostic factors". Current epidemiologic cancer statistics were searched on the internet.

Author contributions: All authors contributed in writing the manuscript and read and approved the final manuscript.

Conflicts of interest statement: The authors state that there are no conflicts of interest regarding the publication of this article.

\section{REFERENCES}

1. Torre LA, Bray F, Siegel RL, Ferlay J, Lortet-Tieulent J, Jemal A. Global cancer statistics, 2012. CA Cancer J Clin 2015;65(2):87-108.

2. Howlader N, Noone AM, Krapcho M, Garshell J, Miller D, Altekruse SF, Kosary CL, Yu M, Ruhl J, Tatalovich Z,Mariotto A, Lewis DR, Chen HS, Feuer EJ, Cronin KA (eds). SEER Cancer Statistics Review, 19752012, National Cancer Institute. Bethesda, MD, https://seer.cancer. gov/archive/csr/1975_2012/, based on November 2014 SEER data submission, accessed on April 2015, cited April 2019.

3. Gillison ML, Broutian T, Graubard B, Pickard R, Tong ZY, Xiao W, Kahle L, Chaturvedi A. Impact of prophylactic human papillomavirus (HPV) vaccination on oral HPV infections among young adults in the U.S. J Clin Oncol 2017;35 suppl; abstr 6003.

4. Institute of Health Information and Statistics of the Czech Republic: Cancer incidence in the Czech republic, 2016. Accessed on October 2018, cited April 2019. Available from: http://www.uzis.cz/katalog/ zdravotnicka-statistika/novotvary

5. Woolgar JA. Histopathological prognosticators in oral and oropharyngeal squamous cell carcinoma. Oral Oncol 2006;42(3):229-39.

6. Chatzistefanou I, Lubek J, Markou K, Ord RA. The role of perineural invasion in treatment decisions for oral cancer patients: A review of the literature. J Craniomaxillofac Surg 2017;45(6):821-5.

7. Liebig C, Ayala G, Wilks J, Verstovsek G, Liu H, Agarwal N, Berger DH, Albo D. Perineural invasion is an independent predictor of outcome in colorectal cancer. J Clin Oncol 2009;27(31):5131-7.

8. Speight PM, Barrett AW. Prognostic factors in malignant tumours of the salivary glands. Br J Oral Maxillofac Surg 2009;47:587-93.

9. Bockman DE, Buchler M, Beger HG. Interaction of pancreatic ductal carcinoma with nerves leads to nerve damage. Gastroenterology 1994;107(1):219-230.

10. Gil Z, Carlson DL, Gupta A, Lee N, Hoppe B, Shah JP, Kraus DH. Patterns and incidence of neural invasion in patients with cancers of the paranasal sinuses. Arch Otolaryngol Head Neck Surg 2009;135(2):173-9.

11. Chen W, Zhang HL, Shao XJ, Jiang YG, Zhao XG, Gao X, Li JH, Yang J, Zhang YF, Liu BL, Sun MY. Gene expression profile of salivary adenoid cystic carcinoma associated with perineural invasion. Tohoku J Exp Med 2007;212(3):319-34.

12. Liebig C, Ayala G, Wilks JA, Berger DH, Albo D. Perineural invasion in cancer: a review of the literature. Cancer 2009;115(15):3379-91.

13. O'Brien CJ, Lahr CJ, Soong SJ, Gandour MJ, Jones JM, Urist MM, Maddox WA. Surgical treatment of early-stage carcinoma of the oral tongue--wound adjuvant treatment be beneficial? Head Neck Surg 1986;8(6):401-8.

14. Soo KC, Carter RL, O'Brien CJ, Barr L, Bliss JM, Shaw HJ. Prognostic implications of perineural spread in squamous carcinomas of the head and neck. Laryngoscope 1986;96(10):1145-8.

15. Fagan JJ, Collins B, Barnes L, D'Amico F, Myers EN, Johnson JT. Perineural invasion in squamous cell carcinoma of the head and neck. Arch Otolaryngol Head Neck Surg 1998;124(6):637-40.

16. Kurtz KA, Hoffman HT, Zimmerman MB, Robinson RA. Perineural and vascular invasion in oral cavity squamous carcinoma: increased incidence on re-review of slides and by using immunohistochemical enhancement. Arch Pathol Lab Med 2005;129(3):354-359.

17. Sutton DN, Brown JS, Rogers SN, Vaughan ED, Woolgar JA. The prognostic implications of the surgical margin in oral squamous cell carcinoma. Int J Oral Maxillofac Surg 2003;32(1):30-4.

18. Binmadi NO, Basile JR. Perineural invasion in oral squamous cell carcinoma: a discussion of significance and review of the literature. Oral Oncol 2011;47(11):1005-10.

19. Jardim JF, Francisco AL, Gondak R, Damascena A, Kowalski LP. Prognostic impact of perineural invasion and lymphovascular invasion in advanced stage oral squamous cell carcinoma. Int J Oral Maxillofac Surg 2015;44(1):23-8.

20. Caldemeyer KS, Mathews VP, Righi PD, Smith RR. Imaging features and clinical significance of perineural spread or extension of head and neck tumors. Radiographics 1998;18(1):97-110; quiz 147.

21. Sullivan LM, Smee R. Leptomeningeal carcinomatosis from perineural invasion of a lip squamous cell carcinoma. Australas Radiol 2006;50(3):262-6.

22. Wallwork BD, Anderson SR, Coman WB. Squamous cell carcinoma of the floor of the mouth: tumour thickness and the rate of cervical metastasis. ANZ J Surg 2007;77(9):761-4.

23. Woolgar JA, Scott J. Prediction of cervical lymph node metastasis in 
squamous cell carcinoma of the tongue/floor of mouth. Head Neck 1995;17(6):463-72.

24. Rahima B, Shingaki S, Nagata M, Saito C. Prognostic significance of perineural invasion in oral and oropharyngeal carcinoma. Oral Surg Oral Med Oral Pathol Oral Radiol Endod 2004;97(4):423-31.

25. Larsen SR, Johansen J, Sorensen JA, Krogdahl A. The prognostic significance of histological features in oral squamous cell carcinoma. $J$ Oral Pathol Med 2009;38:657-62.

26. Ross GL, Soutar DS, MacDonald DG, Shoaib T, Camilleri IG, Robertson AG. 2004. Improved staging of cervical metastases in clinically nodenegative patients with head and neck squamous cell carcinoma. Ann Surg Oncol 2004;11:213-8.

27. Aller MA, Arias Jl, Arias J. Pathological axes of wound repair: gastrulation revisited. Theor Biol Med Model 2010;7:37.

28. Wang L, Sun M, Jiang Y, Yang L, Lei D, Lu C, Zhao Y, Zhang P, Yang Y, Li J. Nerve growth factor and tyrosine kinase $A$ in human salivary adenoid cystic carcinoma: expression patterns and effects on in vitro invasive behavior. J Oral Maxillofac Surg 2006;64(4):636-41.

29. Ayala GE, Dai H, Powell M, Li R, Ding Y, Wheeler TM, Shine D, Kadmon D, Thompson T, Miles BJ, Ittmann MM, Rowley D. Cancer-related axonogenesis and neurogenesis in prostate cancer. Clin Cancer Res 2008;14(23):7593-603.

30. Shah J, Lydiatt WM. Buccal mucosa, alveolus, retromolar trigone, floor of mouth, hard palate and tongue tumors. In: Thawley SE, ed. Comprehensive Management of Head and Neck Tumors. Philadelphia:WB Saunders; 1999. p. 686-693.

31. Brierley JD, Gospodarowicz MK, Wittekind C. TNM Classification of Malignant Tumours. 8th Edition. Wiley Blackwell; 2017.

32. Lee YC, Jung AR, Kwon OE, Kim EJ, Hong IK, Lee JW, Eun YG. Comparison of Computed Tomography, Magnetic Resonance Imaging, and Positron Emission Tomography and Computed Tomography for the Evaluation Bone Invasion in Upper and Lower Gingival Cancers. J Oral Maxillofac Surg 2019;77(4):875.

33. Carter RL, Tsao SW, Burman JF, Pittam MR, Clifford P, Shaw HJ. Patterns and mechanisms of bone invasion by squamous carcinomas of the head and neck. Am J Surg 1983;146(4):451-5.

34. Slootweg PJ, Muller H. Mandibular invasion by oral squamous cell carcinoma. J Craniomaxillofac Surg 1989;17(2):69-74.

35. Wong RJ, Keel SB, Glynn RJ, Varvares MA. Histological pattern of mandibular invasion by oral squamous cell carcinoma. Laryngoscope 2000;110(1):65-72.

36. Charles JF, Aliprantis AO. Osteoclasts: more than 'bone eaters'. Trends Mol Med 2014;20(8):449-59.

37. Crockett JC, Rogers MJ, Coxon FP, Hocking LJ, Helfrich MH. Bone remodelling at a glance. J Cell Sci 2011;124(Pt 7):991-8.

38. Dougall WC. RANKL signaling in bone physiology and cancer. Curr Opin Support Palliat Care 2007;1:317-22

39. Martin CK, Dirksen WP, Shu ST, Werbeck JL, Thudi NK, Yamaguchi M, et al. Characterization of bone resorption in novel in vitro and in vivo models of oral squamous cell carcinoma. Oral Oncol 2012;48(6):491 9.

40. Takayama Y, Mori T, Nomura T, Shibahara T, Sakamoto M. Parathyroidrelated protein plays a critical role in bone invasion by oral squamous cell carcinoma. Int J Oncol 2010;36(6):1387-94.

41. Teixeira LN, de Castro Raucci LMS, Alonso GC, Coletta RD, Rosa AL, de Oliveira PT. Osteopontin expression in co-cultures of human squamous cell carcinoma-derived cells and osteoblastic cells and its effects on the neoplastic cell phenotype and osteoclastic activation. Tumour Biol 2016;37(9):12371-85.

42. Weidle UH, Birzele F, Kollmorgen G, Rüger R. Molecular mechanisms of bone metastasis. Cancer Genomics Proteomics 2016;13(1):1-12.

43. Subarnbhesaj A, Miyauchi M, Chanbora C, Mikuriya A, Nguyen PT, Furusho H, Ayuningtyas NF, Fujita M, Toratani S, Takechi M, Niida S, Takata T. Roles of VEGF-Flt-1 signaling in malignant behaviors of oral squamous cell carcinoma. PLoS One 2017;12(11).

44. Morisawa A, Okui T, Shimo T, Ibaragi S, Okusha Y, Ono M, Nguyen TTH, Hassan NMM, Sasaki A. Ammonium tetrathiomolybdate enhances the antitumor effects of cetuximab via the suppression of osteoclastogenesis in head and neck squamous carcinoma. Int J Oncol 2018;52(3):989-999.

45. Chuang $\mathrm{H}-\mathrm{C}$, Su C-Y, Huang H-Y, Huang C-C, Chien C-Y, Du Y-Y, et al. Active matrix metalloproteinase-7 is associated with invasion in buccal squamous cell carcinoma. Mod Pathol 2008;21:1444-50.

46. Woodward JKL, Holen I, Coleman RE, Buttle DJ. The roles of proteo- lytic enzymes in the development of tumour-induced bone disease in breast and prostate cancer. Bone 2007;41:912-27.

47. Tada T, Jimi E, Okamoto M, Ozeki S, Okabe K. Oral squamous cell carcinoma cells induce osteoclast differentiation by suppression of osteoprotegerin expression in osteoblasts. Int J Cancer 2005;116(2):253-62.

48. Cui N, Nomura T, Takano N, Wang E, Zhang W, Onda T, et al. Osteoclast-related cytokines from biopsy specimens predict mandibular invasion by oral squamous cell carcinoma. Exp Ther Med 2010;1:755-60.

49. Elmusrati AA, Pilborough AE, Khurram SA, Lambert DW. Cancerassociated fibroblasts promote bone invasion in oral squamous cell carcinoma. Br J Cancer 2017;117(6):867-875.

50. Kayamori K, Sakamoto K, Nakashima T, Takayanagi H, Morita K, Omura K, Nguyen ST, Miki Y, limura T, Himeno A, Akashi T, YamadaOkabe H, Ogata E, Yamaguchi A. Roles of interleukin- 6 and parathyroid hormone-related peptide in osteoclast formation associated with oral cancers: significance of interleukin- 6 synthesized by stromal cells in response to cancer cells. Am J Pathol 2010;176(2):968-80.

51. Shibahara T, Nomura T, Cui N-H, Noma H. A study of osteoclast-related cytokines in mandibular invasion by squamous cell carcinoma. Int J Oral Maxillofac Surg 2005;34:789-93.

52. Caja F, Vannucci L. TGF $\beta$ : a player on multiple fronts in the tumor microenvironment. J Immunotoxicol 2015;12(3):300-7.

53. Thiery JP, Lim CT. Tumor dissemination: an EMT affair. Cancer Cell 2013;23(3):272-3.

54. Ozaki-Honda Y, Seki S, Fujiwara M, Matsuura M, Fujita S, Ikeda H, Umeda M, Ayuse T, Ikeda T. Prognostic Prediction of Oral Squamous Cell Carcinoma by E-Cadherin and N-Cadherin Expression in Overall Cells in Tumor Nests or Tumor Cells at the Invasive Front. Cancer Microenviron 2017;10(1-3):87-94.

55. Qiao B, Johnson NW, Gao J. Epithelial-mesenchymal transition in oral squamous cell carcinoma triggered by transforming growth factor beta-1 is Snail family-dependent and correlates with matrix metalloproteinase-2 and -9 expressions. Int J Oncol 2010;37:663-8.

56. Quan J, Du Q, Hou Y, Wang Z, Zhang J. Utilization of E-cadherin by monocytes from tumour cells plays key roles in the progression of bone invasion by oral squamous cell carcinoma. Oncol Rep 2017;38(2):850-858.

57. Massano J, Regateiro FS, Januario G, Ferreira A. Oral squamous cell carcinoma: review of prognostic and predictive factors. Oral Surg Oral Med Oral Pathol Oral Radiol Endodontology 2006;102(1):67-76.

58. Namin AW, Bruggers SD, Panuganti BA, Christopher KM, Walker RJ, Varvares MA. Efficacy of bone marrow cytologic evaluations in detecting occult cancellous invasion. Laryngoscope 2015;125(5): E173-9.

59. Park J, Kim H-J, Kim KR, Lee SK, Kim H, Park K-K, et al. Loss of RUNX3 expression inhibits bone invasion of oral squamous cell carcinoma. Oncotarget 2017;8:9079-92.

60. Dik EA, Ipenburg NA, Adriaansens SO, Kessler PA, van Es RJ, Willems SM. Poor correlation of histologic parameters between biopsy and resection specimen in early stage oral squamous cell carcinoma. Am J Clin Pathol 2015;144(4):659-66.

61. Bobdey S, Mair M, Nair S, Nair D, Balasubramaniam G, Chaturvedi P. A Nomogram based prognostic score that is superior to conventional TNM staging in predicting outcome of surgically treated T4 buccal mucosa cancer: Time to think beyond TNM. Oral Oncol 2018;81:1015.

62. Lundqvist L, Stenlund H, Laurell G, Nylander K. The importance of stromal inflammation in squamous cell carcinoma of the tongue. J Oral Pathol Med 2012;41(5):379-83.

63. Quan J, Zhou C, Johnson NW, Francis G, Dahlstrom JE, Gao J. Molecular pathways involved in crosstalk between cancer cells, osteoblasts and osteoclasts in the invasion of bone by oral squamous cell carcinoma. Pathology 2012;44(3):221-7.

64. Yilmaz T, Jiffar T, de la Garza G, Lin H, Milas Z, Takahashi Y, Hanna E, Maclntyre T, Brown JL, Myers JN, Kupferman ME. Theraputic targeting of Trk supresses tumor proliferation and enhances cisplatin activity in HNSCC. Cancer Biol Ther 2010;10(6):644-53.

65. Wang $L$, Sun $M$, Jiang $Y$, Yang L, Lei D, Lu C, Zhao Y, Zhang P, Yang $Y, \mathrm{Li}$ J. Nerve growth factor and tyrosine kinase A in human salivary adenoid cystic carcinoma: expression patterns and effects on in vitro invasive behavior. J Oral Maxillofac Surg 2006;64(4):636-41.

66. Ketterer K, Rao S, Friess H, Weiss J, Buchler MW, Korc M. Reverse 
transcription-PCR analysis of laser-captured cells points to potential paracrine and autocrine actions of neurotrophins in pancreatic cancer. Clin Cancer Res 2003;9(14):5127-36.

67. Miknyoczki SJ, Lang D, Huang L, Klein-Szanto AJ, Dionne CA, Rugger BA. Neurotrophins and Trk receptors in human pancreatic ductal adenocarcinoma: expression patterns and effects on in vitro invasive behavior. Int J Cancer 1999;81(3):417-27.

68. Muller A, Sonkoly E, Eulert C, Gerber PA, Kubitza R, Schirlau K, Franken-Kunkel P, Poremba C, Snyderman C, Klotz LO, Ruzicka T, Bier H, Zlotnik A, Whiteside TL, Homey B, Hoffmann TK. Chemokine receptors in head and neck cancer: association with metastatic spread and regulation during chemotherapy. Int J Cancer. 2006;118(9):2147-57.

69. Muller MW, Giese NA, Swiercz JM, Ceyhan GO, Esposito I, Hinz $U$, Büchler P, Giese T, Büchler MW, Offermanns S, Friess H. Association of axon guidance factor semaphorin $3 A$ with poor outcome in pancreatic cancer. Int J Cancer. 2007;121(11):2421-33.
70. Madeo M, Colbert PL, Vermeer DW, Lucido CT, Cain JT, Vichaya EG, Grossberg AJ, Muirhead D, Rickel AP, Hong Z, Zhao J, Weimer JM, Spanos WC, Lee JH, Dantzer R, Vermeer PD. Cancer exosomes induce tumor innervation. Nat Commun 2018;9(1):4284.

71. Yoshida S, Shimo T, Murase Y, Takabatake K, Kishimoto K, Ibaragi S, Yoshioka N, Okui T, Nagatsuka H, Sasaki A. The Prognostic Implications of Bone Invasion in Gingival Squamous Cell Carcinoma. Anticancer Res 2018;38(2):955-962.

72. Almela T, Al-Sahaf S, Brook IM, Khoshroo K, Rasoulianboroujeni M, Fahimipour F, Tahriri M, Dashtimoghadam E, Bolt R, Tayebi L, Moharamzadeh K. 3D printed tissue engineered model for bone invasion of oral cancer. Tissue Cell 2018;52:71-77.

73. Jimi E, Shin M, Furuta H, Tada Y, Kusukawa J. The RANKL/RANK system as a therapeutic target for bone invasion by oral squamous cell carcinoma (Review). Int J Oncol 2013;42(3):803-9. 